\title{
DEVELOPMENTAL ASSESSMENT OF INFANTS BORN PRETERM: COMPARISON BETWEEN THE CHRONOLOGICAL AND CORRECTED AGES
}

\author{
Cibelle Kayenne Martins Roberto Formiga ${ }^{1}$, Martina Estevam Brom Vieira², \\ Maria Beatriz Martins Linhares ${ }^{3}$
}

DOI: http://dx.doi.org/10.7322/jhgd.103020

\begin{abstract}
Objective: To compare the global and motor development of infants born preterm, regarding the performance in the chronological age and corrected age for prematurity. Methods: This is a crosssectional study. The sample was comprised of 182 preterm infants (<37 weeks of gestational age) and low birth weight $(<2,500$ grams) belonging to the following age groups: $2-4$ months $(n=182)$, 4-6 months $(n=146)$, and 6-8 months $(n=112)$. The global development was assessed through the Denver-II test in the three age groups, and the motor development was assessed through the Test of Infant Motor Performance in 2-4 months group and the Alberta Infant Motor Scale in 4-6 and 6-8 months group. The infants' performance classifications in the chronological and corrected ages were compared through the McNemar's test. Results: The global and motor development was delayed in $75 \%$ to $91 \%$ of the infants, regarding the chronological age in all three age groups. Otherwise, concerning the corrected age for prematurity, the delayed performance was detected in $33 \%$ to $51 \%$ of the infants in all three age groups $(p<0.001)$. Conclusion: The development assessments taking on the chronological age could overestimate risks and problems in the first year of age.
\end{abstract}

Key words: infant, premature, child development, evaluation.

\section{INTRODUCTION}

Prematurity has been one of the leading causes of death in early childhood and an important risk factor for children's developmental problems ${ }^{1}$. Follow-up services are formed by multidisciplinary teams that carry out systematic monitoring of infants born at risk in order to identify and intervene in problems that may impair their growth and development ${ }^{2}$. The follow-up of preterm infants should be performed through standardized and reliable assessment instruments ${ }^{2,3}$.

The correction of chronological age for prematurity has been commonly used to a more realistic characterization of the development of the preterm infants. According to Blasco ${ }^{4}$, such correction should be carried out from birth to 24 months post-term by subtracting the number of weeks of pregnancy from the total of 40 weeks, which is considered a full-term birth by the World
Health Organization. The difference is then subtracted from the infant's chronological age.

Correction of gestational age was used for many years to assess the development of infants born preterm the same way weight and height development was assessed ${ }^{4-6}$. However, scientific advances in this area has shown that prematurity is not the only risk factor to blame for delays on the rate of motor skill acquisition among infants, since variables such as health complications at birth, maternal practices and environmental conditions are also factors associated with short- and long- term outcomes ${ }^{3}$.

By correcting the gestational age during the first two years of age, it is expected that the sequence of development in preterm infants become similar to that in full-term infants (37-42 weeks of gestational age). However, studies comparing the development of preterm and full-term infants showed that preterm infants show an uneven

1 Physical therapist, PhD in Medical Sciences, Associate Professor, Department of Physical Therapy of the State University of Goiás (UEG), Goiânia, GO, Brazil.

2 Physical Therapist, Master of Science, Assistant Professor, Department of Physical Therapy of the State University of Goiás (UEG), Goiânia, GO. Doctoral student, Department of Neurosciences and Behavior, Ribeirão Preto Medical School, University of São Paulo, Ribeirão Preto, SP, Brazil.

3 PhD in Psychology, Associate Professor, Department of Neurosciences and Behavior, Ribeirão Preto Medical School, University of São Paulo, Ribeirão Preto, SP, Brazil.

Corresponding author: CibelleKayenne Martins Roberto Formiga. E-mail: cibellekayenne@gmail.com

Suggested citation: Formiga CKMR, Vieira MEB, Linhares MBM. Developmental assessment of infants born preterm: comparison between the chronological and corrected ages. Journal of Human Growth and Development. 25(2): 230-236. DOI: http://dx.doi.org/10.7322/ jhgd.103020

Manuscript submitted: feb 22 2015. Accepted for publication: jul 102015. 
pattern of development, which is not always delayed when compared to that of children born at term ${ }^{7-10}$.

Although routinely adopted, age correction for prematurity is still a matter of controversy in the literature. Classic studies ${ }^{4-6,11}$ on this subject date back from many years ago and do not consider whether there are different forms of age correction according to the areas of children's development and until what age the correction should be done, such as in gross motor development, which seems to be more influenced by gestational age, whereas fine motor development seems to result from the interaction of maturational/biological factors and environmental factors ${ }^{12}$.

In order to contribute to the discussion about age limit for correction, another study analyzed the motor development of low-risk preterm infants up to 12 months of age ${ }^{13}$. The authors found the need for age correction of preterm babies in the first year of life regardless of gestational age, and that there would be no need for correction for prematurity from 13 months of corrected age ${ }^{13}$.

The most accepted assumption nowadays is that preterm infants evaluated considering the corrected age may show the same skill level of fullterm infants in gross motor development between eight and 12 months of age ${ }^{14}$. But when using chronological age, the motor development of preterm infants with low risk of neurological disorders is underestimated, leading to a falsenegative diagnosis of motor development delay ${ }^{13}$.

A systematic review of the literature ${ }^{15}$ showed that further studies were still needed to assess corrected age when considering the use of standardized tests in their latest versions. As far as we know, new studies dated from the last five years regarding the comparison of development of preterm infants in chronological and corrected ages have not been found. In this sense, this issue still seems to need to be further investigated.

Given this gap in the literature, this paper contributes to the update of the subject, in addition to addressing global and motor development through several different assessment tools in the first year of post-natal age.

The aim of the study was to compare global and motor development indicators of preterm infants in the first post-natal year, taking into account the performance of children in the chronological age and in the corrected age for prematurity.

\section{METHODS}

This is a cross-sectional study based on intragroup comparison analysis (classification of motor development: chronological age versus corrected age).

The total sample consisted of 182 newborns born preterm (gestational age less than 37 weeks) and with low birth weight (less than 2,500 grams), assessed during their first year of life. They were born at Materno Infantil Hospital in Goiânia (GO), Brazil, from 2004 to 2007. Newborns without congenital abnormalities were included as well as those who were clinically stable on the first day of assessment. Of twins, only one was randomly included. From 275 children of the initial sample who met the inclusion criteria, nine twins were excluded, 18 children became clinically unstable, 32 mothers were discharged without signing the informed consent form, and 34 mothers refused to participate in the study.

The initial sample of 182 infants was assessed in three separate age groups (sub-samples): at 24 months, all the babies were assessed $(n=182)$, at 4-6 months $(n=146)$, and at 6- 8 months $(n=112)$ of chronological age. It can be observed that some infants were included in more than one age group and that each group did not have exactly the same infants, since some were lost during the follow-up and others attended only at the initial assessment and at the third evaluation.

The infants were evaluated by the following instruments:

a) Denver Developmental Screening Test (DDST-II) ${ }^{16}$; Brazilian version ${ }^{17}$. The DDST-II is a test for screening developmental problems in children. It can be used in children from birth to six years of age. The test consists of 125 items and assesses child's development in four general areas: personalsocial, language, fine motor and gross motor. Some items are applied by asking the child to perform specific tasks. Others consider parent/guardian report about the child's performance. Inter-raters and test-retest reliability is $\mathrm{e}^{\prime \prime} 0.75^{16}$. The test performance is ranked as "normal" or as "at risk for developmental delay". In the present study, we considered the overall performance of the child in DDST-II considering the responses in the four domains assessed and for the 2-8 months of age.

b) Test of Infant Motor Performance (TIMP) ${ }^{18}$. The TIMP is a standardized test that assesses postural and selective control of movement needed for functional motor performance in infants, validity from 34 weeks' post-conceptional age to four months post-term is of 0.83 and 0.85 for motor development and clinical risk ${ }^{19}$, respectively. The predictive validity of TIMP for motor performance on the Alberta Infant Motor Scale (AIMS) at 12 months is $0.88^{20}$. Total scores are graded according to the mean and standard deviation (SD) of the standardization sample of the test. In the present study, we adopted the following classification: normal motor development (score between 1 SD above and below the mean) and abnormal (score lower than 1 SD below the mean).

c) Alberta Infant Motor Scale (AIMS). The AIMS evaluates the weight bearing, posture and antigravity movements in the gross motor development in infants up to 18 months of age. Previous studies showed that this instrument can be applied to samples with various clinical characteristics 7,22 , besides showing an interobserver agreement of $>0.96$ and test-retest reliability ranging from 0.86 to $0.99^{23}$. Concurrent validity (8-13 months) with other standard motor assessments (such as Bayley Scales) ranges from 0.84 to $0.99^{24,25}$. The sensitivity ranges from $76 \%$ to $86 \%$, whereas the specificity ranges from $82 \%$ to $93 \%$, depending on the age of the infant ( 4 to 8 
months) and the $10^{\text {th }}$ percentile was established as the cutoff point for developmental delay ${ }^{24,25}$. The score for each position (prone, supine, sitting and standing) is summed to the final score. The latter is inserted into the normative chart for the classification of the percentile score according to the infant's age. In this study, infants' motor performance was divided into two categories: normal (percentile $>10$ ) and abnormal (percentile $\left.d^{\prime \prime} 10\right)$.

d) Clinical Record. Infants' health history, including neonatal data (admission, birth weight, gestational age, length of stay, Apgar score in the fifth minute and results of cranial ultrasound examinations) was recorded in the medical records. The results of the ultrasound examinations were rated as normal (no detectable brain lesions) and abnormal (with brain lesions, such as intraventricular hemorrhage and periventricular leukomalacia).

e) Clinical Risk Index for Babies-II (CRIB-II). Neonatal clinical risk within the first 12 postnatal hours was assessed by CRIB-II, which results in a score of 0 (zero) to 27 . The higher the score, the worst the neonatal clinical condition ${ }^{26}$.

As for data collection procedures, the total sample of 182 infants was assessed, and data collection was performed in three independent age groups, i.e., in three sections according to age group: at 2-4 months ( $n=182)$, at 4-6 months ( $n$ $=146)$ and at $6-8$ months $(n=112)$ of corrected age. DDST-II was administered in all three age groups. The TIMP was applied only in the 2-4 months group. The AIMS assessment was performed in the groups of infants aged 6-8 months and 4-6 months. The children's assessments were made during a medical appointment and lasted about 40 minutes. The infants were fed at the maximum up until one hour before the examination.

The team was formed by eight trained physical therapists and was supervised by the first author. All the assessments were recorded with a Sony HC-40 digital camera. At each appointment, two examiners of the team carried out the assessment of the children. One of them carried out test procedures with the children and the other recorded it digitally. The medical records were reviewed to obtain health history information about the children.

Two other independent and blind evaluators of the team analyzed the video recordings and recorded the performances of the infants, considering both corrected age and chronological age when analyzing test results. The rates of agreement among evaluators were obtained for all instruments using the following equation: Agreement / (Agreement + Disagreement) X 100 . The results were as follows: $90 \%$ for DDST-II, $80 \%$ for TIMP and $81 \%$ for the AIMS.

Descriptive statistical analysis included the calculation of the mean, standard deviation and range of variation for continuous variables, and frequencies and percentages for categorical variables. Comparisons between the performance ratings of infants in the DDST-II, TIMP and AIMS were carried out by using the McNemar's test. So, for every age group, the classification of development (risk/ abnormal versus normal) was analyzed with respect to the age (chronological age versus corrected age) of each child (paired). The Statistical Package for Social Sciences (SPSS, version 19.0, Chicago , Il, USA) was used for data analysis. The significance level of $5 \%$ was used.

The study was approved by the Research Ethics Committee of the General Hospital in GoiâniaGO (protocol number 73/2004). The parents signed the free informed consent form.

\section{RESULTS}

Table 1 shows the characteristics of the children in the study. It is observed that the sample consisted mostly of male children who were born with mean gestational age of 32 weeks and five days and low birth weight (an average weight of 1,645 grams), and stayed in hospital after birth for about a month in average.

Figure 1 shows the comparison of children's global development according to their performance in the corrected age and in the chronological age. When the corrected age was considered, global development of 33-51\% of the children was classified as at risk according to the DDST-II in the three age groups. On the other hand, when assessment is made based on chronological age, the risk for overall developmental delay increased significantly to $75-91 \%$ in the three age groups ( $p$ $<0.001$ in all comparisons).

The comparison of children's motor development considering chronological age and corrected age is in Figure 2. When analyzing the performance of children in corrected age, the motor development of $36-48 \%$ of the sample was classified as abnormal in the three age groups. When considering chronological age, the rate of changes in motor development increased significantly to 71$88 \%$ in the three age groups $(p<0.001$ in all comparisons).

\section{DISCUSSION}

This study analyzed global and motor development of infants born preterm comparing their performance according to their chronological and corrected ages. The infants studied are considered as "at risk" for developmental problems due to the presence, besides prematurity, of other risk factors such as low birth weight, abnormalities detected in cranial ultrasound examinations and the use of mechanical ventilation at birth.

The results showed that the percentage of infants with global and motor developmental delays increased significantly when considering their performance according to chronological age when compared to corrected age. In this sense, it could be found in the at-risk sample of the present study that not correcting the child's age at the time of assessment may overestimate risks that are not in fact problems in children's development. These findings suggest that correcting age is the best way to assess the actual performance of at risk preterm infants. 
Table 1: Characteristics of the infants of the study sample (n=182), Goiânia-GO, 2004-2007

\begin{tabular}{|c|c|}
\hline Characteristics & Values \\
\hline \multicolumn{2}{|l|}{ Delivery - n (\%) } \\
\hline Vaginal & $92(50.54)$ \\
\hline Cesarean & $90(49.46)$ \\
\hline \multicolumn{2}{|l|}{ Gender - n (\%) } \\
\hline Female & $78(42.85)$ \\
\hline Male & $104(57.15)$ \\
\hline \multicolumn{2}{|l|}{ Birth weight (in grams) } \\
\hline Mean (SD) & $1.645( \pm 424)$ \\
\hline Range & $580-2.495$ \\
\hline \multicolumn{2}{|l|}{ Gestational age (in weeks) } \\
\hline Mean (SD) & $32.7( \pm 2.2)$ \\
\hline Range & $24-36$ \\
\hline \multicolumn{2}{|l|}{ Apgar score in the $5^{\text {th }}$ minute } \\
\hline$<7$ & $19(10.4)$ \\
\hline$\geq 7$ & $169(89.6)$ \\
\hline \multicolumn{2}{|c|}{ Clinical Risk Index for Babies-II (CRIB-II) } \\
\hline Mean (SD) & $1.7( \pm 2.5)$ \\
\hline Range & $0-15$ \\
\hline \multicolumn{2}{|l|}{ Neonatal cranial ultrasound - n (\%) } \\
\hline Normal & $132(72.53)$ \\
\hline Abnormal* & $50(27.47)$ \\
\hline Retinopathy of prematurity - n (\%) & $5(2.74)$ \\
\hline Hearing impairment - $\mathrm{n}(\%)$ & $3(1.64)$ \\
\hline Mechanical ventilation - n (\%) & $30(16.48)$ \\
\hline \multicolumn{2}{|l|}{ Length of hospital stay (days) } \\
\hline Mean (SD) & $32.6( \pm 25.2)$ \\
\hline Range & $1-155$ \\
\hline
\end{tabular}

Note: $\mathrm{n}$ (number of participants); \% (percentage); SD (standard deviation).

* Abnormal cranial ultrasound results included 26 newborns with intraventricular hemorrhage, 19 had periventricular leukomalacia and 5 had ventricular dilatation.

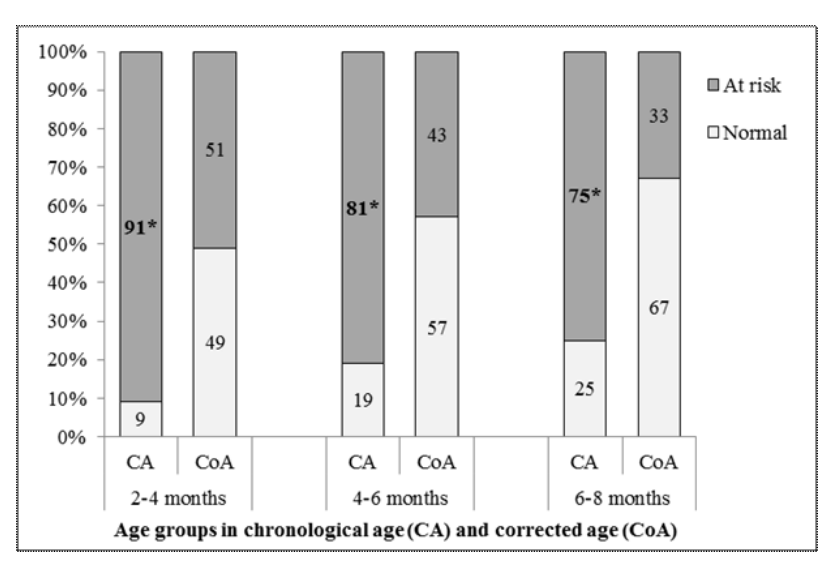

Figure 1: Global development classification in infants assessed according to DDST-II, as per chronological age (CA) and corrected age (CoA), Goiânia-GO, 2004-2007. $* \mathrm{p}<0,001$ - comparison CA versus CoA.

The results of this study are consistent with previous studies, 6,13,27-29. Regarding the assessments of gross motor skills, Zaniniet al. ${ }^{9}$ investigated the period of sitting, crawling and walking acquisitions in 46 preterm and full-term infants using the AIMS and found that $20 \%$ of premature infants needed to be sent to physical therapy once they showed significant delays. Restiffe and Gherpelli's 13 study compared the motor development of preterm infants up to 12

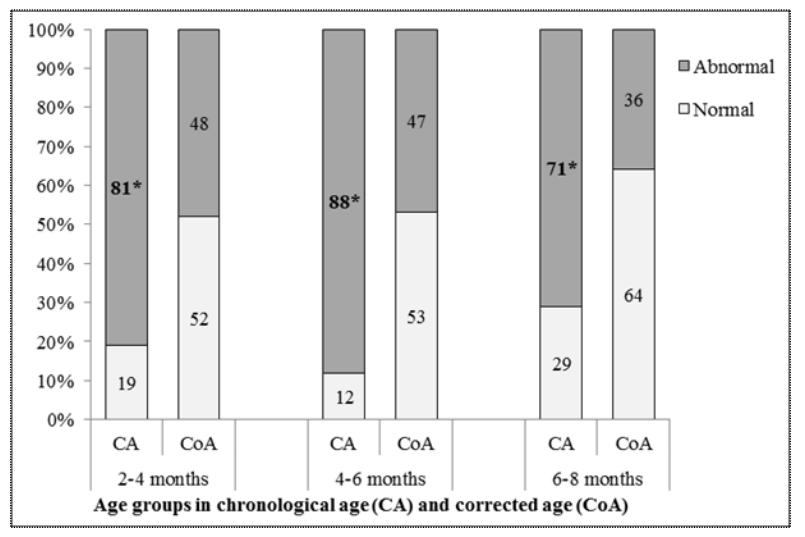

Figure 2: Motor development classification in infants assessed according to TIMP in the $2-4$ months $(n=182)$ and to AIMS in the 4-6 months $(n=146)$ and 6-8 months $(n=112)$ age groups, as per chronological age $(C A)$ and corrected age (CoA), Goiânia-GO, 2004-2007.

$* p<0,001$ - comparison CA versus CoA.

months of age by using chronological and corrected ages. The research of Albuquerque et al. ${ }^{29}$ analyzed visual motor development in the first month of age using the "Assessment Method of Infant Visual Behavior" according to chronological and corrected ages. The findings of this study, in accordance with those previous studies, confirm the need to consider corrected age in the first year of age, once this period is essential for the acquisition of motor skills. 
In contrast, some studies disagree with the results of this research, once they do not consider necessary to correct the age for motor development of preterm infants in the first four months ${ }^{10}$ and at two years of age ${ }^{8}$. However, the age groups of those studies are not the same age groups of this study, and preterm infants are low-risk (gestational age 31-36 weeks, classified as adequate weight for gestational age $[\mathrm{AGA}]$ and Apgar score $>7$ at the fifth minute) ${ }^{10}$. In addition, in both studies the reference sample consisting of full-term was used, whereas in the present study preterm infant performance was compared by using both ages.

Another distinguishing feature of this study is to use both a screening instrument (DDST-II) and a test and assessment scale of infant motor development (TIMP and AIMS) in the first year of the infant's life. The literature suggests that the application of standardized and reliable assessment instruments minimizes the chance of misdiagnosis and offers the examiner the tools to monitor the development of preterm infant in the long term ${ }^{16-25}$.

By only using the infant's chronological age without performing the age correction for prematurity puts full-term and preterm infants within the same level of development and, as it was stated in this study, premature birth is accompanied by a number of other adversities, in addition to being born ahead of schedule, such as: health problems, prolonged hospital stay, need for ventilatory support, neurosensory (visual or auditory) impairments, among others, which can compromise development ${ }^{1,30-32}$.

In the present study, although the development of the child was assessed up to eight months of corrected age, it is observed that in the first year of life it is necessary to correct the age of the preterm infant. Based on the literature studied, such correction does not seem to be necessary when the chronological age of the infant is close to 18 months. However, professionals should also consider some other factors involved in the assessment process, such as prematurity level (extreme, moderate or late), birth weight, neonatal clinical risk, presence or absence of lesions in the cranial ultrasound examination and time of hospital stay. These factors can increase the chance of developmental problems in infants ${ }^{3,32}$.

\section{REFERENCES}

1. World Health Organization (WHO). Born too soon: the global action report on preterm birth. Geneva: World Health Organization; 2012.

2. Formiga CKMR, Linhares MBM. Follow-up do desenvolvimento do bebê de risco. In: Sarmento GJV. Fisioterapia respiratória em pediatria e neonatologia. 2. ed. Barueri: Manole, 2011; p.556-73.

3. Vieira ME, Linhares MB. Developmental outcomes and quality of life in children born preterm at preschool- and school-age. J Pediatr (Rio J). 2011; 87(4): 281-91. DOI: http://dx. doi.org/10.2223/JPED.2096
It is noteworthy that measures of prevention and health promotion are priorities in public health programs and health policies. The approach to disease prevention in child development is not out of this strategy, which aims professional qualification within groups at risk and greater efficiency of health services. Health strategies also depend on social and economic measures to thrive ${ }^{33,34}$.

A practical recommendation for the monitoring of infants at risk of developmental delay or deviation is to analyze their performance considering their age and medical history. In some cases, only the informational support for caregivers on how to promote children's healthy development and provide a stimulating environment can minimize delays. If delays or abnormalities are discovered, it is recommended to seek skilled health professionals, who should analyze how delayed development is, as well as check if the child is following the expected growth curve, and whether the family is demonstrating competence in taking care of the child or not and, if necessary, refer the child to a specialized intervention service ${ }^{35,36}$.

Therefore, it is advisable to correct the age of infants born preterm, especially with regard to their first year of life. Thus, each professional must apply the age correction rule according to the specificity of his practice field and considering the child's health history and family background.

As limitations of the study, we can mention that longitudinal design is not shown and that children in the age-groups above 12 months of age were not assessed. Therefore, there was no comparison between those and the results obtained. These aspects can be addressed in future studies.

\section{Acknowledgements}

We are grateful for financial support provided by the National Council for Scientific and Technological Development ("CNPq") to CKMR Formiga (Grant no. 142268/2005-4), MEB Vieira (Grant no. 131100/2010-6) and MBM Linhares (Researcher with productivity grant - Level 1-A). The authors wish to thank the staff of the "Hospital Materno Infantil" of Goiânia, the team of college students of the "Programa de Follow-up do Bebê de Risco", the children and their families, and Cássio dos Reis for the support in statistics.

4. Blasco P. A preterm birth: to correct or not correct. Dev Med Child Neurol. 1989; 31(6): 816-21. DOI: http://dx.doi.org/10.1111/ j.1469-8749.1989.tb04080.x

5. Lems W, Hopkins B, Samson JF. Mental and motor development in preterm infants: the issue of corrected age. Early Hum Dev. 1993; 3491-2): 113-23. DOI: http://dx.doi.org/ 10.1016/0378-3782(93)90046-W

6. Matilainen $\mathrm{R}$. The value of correction for age in the assessment of prematurely born children. Early Hum Dev. 1987; 15(5): 257-64. DOI: http://dx.doi.org/10.1016/0378-3782 (87) $90048-X$

7. Formiga CKMR, Linhares MBM. Motor development curve from 0 to 12 months in 
infants born preterm. Acta Paediatr. 2011; 100(3): 379-84. http://dx.doi.org/10.1111/ j.1651-2227.2010.02002.x

8. Mancini MC, Carvalho DJ, Gontijo DT. Efeitos da correção da idade gestacional no desempenho motor grosso e fino de crianças pré-termo aos dois anos de idade. Temas Desenvolv. 2002; 11(64): 12-9.

9. Zanini PQ, Hayashida M, Hara PS, Lima AC, Castro SS, Bueno CF, et al. Análise da aquisição do sentar, engatinhar e andar em um grupo de crianças pré-termo. Fisioter Pesquisa. 2002; 9(2): 57-62. DOI: http://dx.doi.org/10.1590/ fpusp.v9i2.79653

10. Raniero EP, Tudella E, Mattos RS. Padrão e ritmo de aquisição das habilidades motoras de lactentes pré-termo nos quatro primeiros meses de idade corrigida. Rev Bras Fisioter. 2010; 14(5): 396-403. DOI: http://dx.doi.org/ 10.1590/S1413-35552010000500008

11. Miller G, Dubowitz LMS, Palmer P. Follow-up of preterm infant: is correction of developmental quotiente for prematurity helpful? Early Hum Dev. 1984; 9(2): 137-44. DOI: http:// dx.doi.org/10.1016/0378-3782(84)90094-X

12. Piper MC, Byrne PJ, Darrah J, Watt MJ. Gross and fine motor development of preterm infants at eight to 12 months of age. Dev Med Child Neurol. 1989; 31(5): 591-7. DOI: http:// dx.doi.org/10.1111/j.1469-8749.1989. tb04044.x

13. Restiffe AP, Gherpelli JLD. Comparison of chronological and corrected ages in the gross motor assessment of low-risk preterm infants during the first year life. Arq Neuropsiquiatr. 2006; 64(2b): 418-25. DOI: http://dx.doi.org/ 10.1590/S0004-282X2006000300013

14. Mancini MC, Teixeira S, Araújo LG, Paixão ML, Magalhães LC, Coelho ZAC, et al. Estudo do desenvolvimento da função motora aos 8 e 12 meses de idade em crianças nascidas pré-termo e a termo. Arq Neuropsiquiatr. 2002; 60(4): 974-80. DOI: http://dx.doi.org/10.1590/ S0004-282X2002000600017

15. D'Agostino JA. An evidentiary review regarding the use of chronological and adjusted age in the assessment of preterm infants. J Spec Pediatr Nurs. 2010; 15(1): 26-32. DOI: http:/ /dx.doi.org/10.1111/j.1744-6155.2009. 00215.x

16. Frankenburg WK, Dodds JB, Archer P, Shapiro $\mathrm{H}$, Bresnick B. The Denver II: a major revision and restandardization of denver developmental screening test. Pediatrics. 1992; 89(1): 91-7.

17. Figueiras ACM, Souza ICN, Rios VG, Benguigui Y. Manual para vigilância do desenvolvimento infantil no contexto da AIDPI. Washington: OPAS, 2005.

18. Campbell SK, Kolobe THA, Osten ET, Lenke M, Girolami G. The Test of infant motor performance. Test user's manual version 1.4. Copyright Suzann K. Campbell; 2001.

19. Campbell SK, Kolobe THA, Osten ET, Lenke M, Girolami G. Construct validity of the Test of infant motor performance. Phys Ther. 1995; 75(7): 585-96.
20. Campbell SK, Kolobe THA, Wright B, Linacre JM. Validity of Test of Infant Motor Performance for prediction of 6, 9 and 12 month scores on the Alberta Infant Motor Scale. Dev Med Child Neurol. 2002; 44(4): 263-72.

21. Piper MC, Darrah J. Motor assessment of the developing infant. EUA: W.B. Saunders Company; 1994.

22. Herrero D, Gallo PR, Fujimori M, Monteiro CBM, Valenti VE, Tavares CM, et al. Motor development of infants exposed to maternal human immunodeficiency virus (HIV) but not infected. Int Arch Med. 2013; 6:45. DOI: http:/ /dx.doi.org/10.1186/1755-7682-6-45

23. Piper MC, Pinnell LE, Darrah J, Maguire T, Byrne PJ. Construction and validation of the Alberta Infant Motor Scale. Can J Public Health. 1992; 83(Suppl. 2): S46-50.

24. Darrah J, Piper MC, Watt M. Assessment of gross motor skills of at-risk infants: predictive validity of the Alberta Infant Motor Scale. Dev Med Child Neurol. 1998; 40(7): 485-91.

25. Santos RS, Araújo APQC, Porto MAS. Early Diagnosis of abnormal development of preterm newborns: assessment instruments. J Pediatr (Rio J). 2008; 84(4): 288-99. DOI: http:// dx.doi.org/10.2223/JPED. 1815

26. Parry G, Tucker J, Tarnow-Mordi W; UK Neonatal Staffing Study Collaborative Group. CRIB II: an update of the clinical risk index for babies score. Lancet. 2003; 361(9371): 1789-91.

27. Volpi SCP, Rugolo LMSS, Peraçoli JC, Corrente JE. Aquisição de habilidades motoras até a marcha independente em prematuros de muito baixo peso. J Pediatr (Rio J). 2010; 86(2): 143-148. DOI: http://dx.doi.org/10.2223/ JPED. 1989

28. Den Ouden L, Rijken M, Brand R, VerlooveVanhorick SP, Ruys JH. Is it correct to correct? Developmental milestones in 555 "normal" preterm infants compared with term infants. J Pediatr. 1991;118(3):399-404. DOI: http:// dx.doi.org/10.1016/S0022-3476(05)82154-7

29. Albuquerque RC, Gagliardo HG, Lima AC, Guerra MQ, Rabelo AR, Cabral-Filho JE. Visuomotor behaviour of preterm infants in the first month of life. A comparison between the chronological and corrected ages. Rev Neurol. 2009; 48(1):13-6.

30. Araújo PPC, Moura FOF, Valenti VE, Gallo MS, Camargo MR, Say KG, et al. Stabilometric parameters analysis in children with visual disorder. Int Arch Med. 2014; 7:1. DOI: http:/ /dx.doi.org/10.1186/1755-7682-7-1

31. Nicolau CM, Costa APBM, Hazime OH, Krebs VLJ. Desempenho motor em recém-nascidos pré-termo de alto risco. Rev Bras Crescimento Desenvol Hum. 2011; 21(2): 327-34.

32. Synnes A, Anderson PJ, Grunau RE, Dewey D, Moddemann D, Tin W, et al. Predicting severe motor impairment in preterm children at age 5 years. Arch Dis Child. 2015; 100(8): 748-53. DOI: http://dx.doi.org/10.1136/archdischild2014-307695

33. Silva DI, Veríssimo MOR, Mazza VA. Vulnerability in the child development: influence 
of public policies and health programs. J Hum Growth Dev. 2015; 25(1): 11-18. DOI: http:// dx.doi.org/10.7322/jhgd.96760

34. Kirigia JM, Kirigia DG. The essence of governance in health development. Int Arch Med. 2011; 4:11. DOI: http://dx.doi.org/ 10.1186/1755-7682-4-11

35. Guimarães FAB, Assis CD, Vieira MEB, Formiga CKMR. Evaluation of teaching materials prepared for guidance of caregivers and day care teachers on child development. J Hum Growth Dev. 2015; 25(1): 27-40. DOI: http:// dx.doi.org/10.7322/jhgd.96764

36. Silva J, Fronio JS, Lemos RA, Ribeiro LC, Aguiar TS, Silva DT, et al. Pacing opportunities at home and skill of children with potential changes in functional development. J Hum Growth Dev. 2015; 25(1): 19-26. DOI: http://dx.doi.org/ $10.7322 /$ jhgd. 96763

\section{Resumo}

Objetivo: Comparar o desenvolvimento global e motor de bebês nascidos pré-termo, considerandose o desempenho das crianças na idade cronológica e na idade corrigida para a prematuridade. Método: O estudo é do tipo corte-transversal. A amostra foi constituída por um total de 182 recémnascidos pré-termo ( $<37$ semanas de idade gestacional) e com baixo peso ao nascer $(<2.500$ gramas) pertencentes aos seguintes grupos etários: $2-4$ meses $(n=182)$, 4-6 meses $(n=146)$ e 6-8 meses $(n=112)$. O desenvolvimento global das crianças foi avaliado pelo Teste de Denver II nos três grupos etários e o desenvolvimento motor foi avaliado pelo Test of Infant Motor Performance no grupo de 2-4 meses e pela Alberta Infant Motor Scale nos grupos de 4-6 e 6-8 meses. A classificação dos desempenhos das crianças, considerando-se as idades cronológica e corrigida, foi comparada por meio do Teste de McNemar. Resultados: Quando se considera a idade cronológica, o percentual de atraso no desenvolvimento motor e global situou-se entre $75 \%$ e $91 \%$ da amostra, porém utilizando a idade corrigida este percentual variou de $33 \%$ a $51 \%$, considerando os três grupos etários ( $p<0,001)$. Conclusão: $A$ avaliação do desenvolvimento utilizando a idade cronológica pode superestimar riscos ou problemas no primeiro ano de idade.

Palavras-chave: prematuro, desenvolvimento infantil, avaliação. 